\title{
A Comparative Assessment of Fertilizers and Natural Organics on Yield and Seed Quality Attributes of Blackgram
}

\author{
Y. Bhargavi*, P. Sudhakar, V. Raja Rajeswari and T. Giridhara Krishna \\ Department of Crop Physiology, Agricultural College, Bapatla, India \\ *Corresponding author
}

\section{A B S T R A C T}

\section{Keywords}

Aminoacid, Beejamrutha, Blackgram, Fertilizers, Jeevamrutha, Protein

Article Info

Accepted: 12 April 2021 Available Online: 10 May 2021
A field experiment was conducted during Kharif, 2017 at dry land farm, S.V.Agricultural college, Tirupati to study the influence of natural liquid organics on yield and seed quality attributes of blackgram. The experiment was conducted in RBD with 10 treatments (Recommended dose of fertilizers (RDF), RDF+ Seed treatment with water, Seed treatment with beejamrutha, soil application of ghanajeevamrutha, foliar spray of jeevamrutha, foliar spray of panchagavya, soil application of ghanajeevamrutha+ foliar spray of jeevamrutha, soil application of ghanajeevamrutha+ foliar spray of panchagavya and integrated use of above mentioned organics) with 3 replications. Significantly higher seed yield and yield attributes were recorded with RDF and RDF with seed treatment with water in blackgram. However, combined application of natural organics recorded on par seed yield with the two inorganic treatments. Post-harvest seed quality attributes viz., carbohydrate content, protein content, total sugars did not differ significantly among different treatments. Significantly higher catalase and superoxide dismutase activities of seed were found in the treatments RDF and seed treatment with water along with RDF followed by combined organic application treatment.

\section{Introduction}

Blackgram (Vigna mungo L.) is one of the most widely grown grain legumes and belongs to the family fabaceae and assumes considerable importance from the point of nutritional security. It is an annual herbaceous plant consumed in the form of 'dal' and also used as a nutritive fodder for mulch cattle. Blackgram is rich in its nutritive value with 24 per cent protein and is the richest source of phosphoric acid among pulses (Singh, 2009). In India, blackgram is grown in an area of 761.3 thousands hectares, with a production of 678.6 thousand tonnes and with a productivity of $891.0 \mathrm{~kg} \mathrm{ha}^{-1}$.

In Andhra Pradesh, it covers an area of 296 thousands of hectares, with a production of 277 thousands of tonnes and with a 
productivity of $936 \quad \mathrm{~kg} \quad \mathrm{ha}^{-1}$. (www.Indiastat.com). There is a scope to improve the productivity of pulses by enhancing the soil fertility and its productivity through increasing soil organic carbon, soil moisture storage capacity and adopting integrated nutrient and pest management practices.

Natural farming is the new method introduced to overcome this disadvantage by producing better yield and maintaining soil health within short period. Natural farming is the method which employs the usage of naturally available products. Some of the inputs used in natural farming include panchagavya, jeevamrutha, beejamrutha etc. (Lakshmipathi, 2012). Foliar application of nutrients using water soluble fertilizer is one of the possible ways to enhance the productivity of pulses like blackgram (Shyamrao et al., 2016).

Hence the present investigation is taken up to study the effect of natural liquid organics on yield and seed quality attributes of blackgram.

\section{Materials and Methods}

The present field experiment was carried out at S.V. Agricultural College dryland Farm, Tirupati campus of Acharya N.G. Ranga Agricultural University during kharif, 2017 which is geographically situated at an altitude of $182.9 \mathrm{~m}$ above mean sea level on $79.5^{\circ} \mathrm{E}$ longitude and $13.5^{\circ} \mathrm{N}$ latitude.

During the crop growth period, $738 \mathrm{~mm}$ of rainfall was received in 33 rainy days, as against the decennial average of $334.45 \mathrm{~mm}$ received in 20 rainy days for the corresponding period. The experiment was laid out in a randomized block design (RBD) consisting of ten treatments in three replications. The weekly mean maximum temperature during the crop growth period ranged from 30.8 to $38.5^{\circ} \mathrm{C}$ with an average of $33.48^{\circ} \mathrm{C}$. The decennial mean maximum temperature for the corresponding period ranged from 33.43 to $35.32^{\circ} \mathrm{C}$ with an average of $34.09^{\circ} \mathrm{C}$. The weekly mean relative humidity during the crop period ranged from 45.1 to 80.6 per cent with an average of 68.55 per cent. Soil of the experimental site was studied for physico-chemical properties and the results revealed that the soil was sandy clay loam in texture, slightly neutral in soil reaction ( $\mathrm{pH}-7.1)$, low in available nitrogen (175 kg ha ${ }^{-1}$ ) and organic carbon $(0.45 \%)$, medium in available phosphorus $\left(28 \mathrm{~kg} \mathrm{ha}^{-1}\right)$ and available potassium $\left(204 \mathrm{~kg} \mathrm{ha}^{-1}\right)$. The experiment was laid out in randomised block design with 3 replications and 10 treatments.

$\mathrm{T} 1$ : Recommended dose of fertlizers

$\mathrm{T} 2: \mathrm{T}_{1}$ (except the seed treatment with water)

T3 : Seed treated with Beejamrutha

T4 : Soil application of Ghanajeevamruta as basal

T5 : Foliar sprays of Jeevamrutha @3\% (Every 10 days)

T6 : Foliar sprays of Panchagavya @3\% (Every 10 days)

T7 : Seed treated with Beejamrutha (T3) +Soil Application of Ghanajeevamruta as basal (T4)

T8 : Soil application of Ghanajeevamruta as basal (T4) + Foliar sprays of Jeevamrutha @ 3\% (Every 10 days) (T5)

T9 : Soil application of Ghanajeevamruta as basal (T4) + Foliar sprays of Panchagavya @ 3\% (Every 10 days) (T6)

T10 : Seed Treated with Beejamrutha (T3) + Soil Application of Ghanajeevamruta as basal (T4) + Foliar sprays of Jeevamrutha @ 3\% (Every 10 days) (T5) + Foliar sprays of Panchagavya @3\% (Every 10 days) (T6) 
The plot was ploughed twice by tractor drawn plough. The field was finally leveled with wooden plank and the plots were laid out according to the layout plan.

Blackgram variety TBG-104 was sown in line with $30 \mathrm{~cm}^{*} 10 \mathrm{~cm}$ spacing. Recommended dose of fertilizers (20-40-40 N, $\mathrm{P}_{2} \mathrm{O}_{5}, \mathrm{~K}_{2} \mathrm{O} \mathrm{kg}$ $\mathrm{ha}^{-1}$ ) were supplied through chemical fertilizers (urea, single super phosphate and muriate of potash) in $T_{1}$ and $T_{2}$ treatmental plots at the time of sowing. The organics were supplied to the plots as per the treatments.

Along with liquid organics, solid organic i.e. Ghanajeevamruta was applied as basal to soil (according to the treatments), because without soil enrichment, liquid organics potentiality cannot be explored.

The natural organics, panchagavya, jeevamrutha, beejamruta were supplied as per the treatments. Yield attributes and yield $(\mathrm{kg}$ $\mathrm{ha}^{-1}$ ) were recorded and analyzed statistically for interpretation.

Seed quality attributes viz., total aminoacids, carbohydrates, protein, total soluble sugars and antioxidant enzyme activity viz., catalase, superoxide dismutase of the seed were recorded and analyzed.

Total aminoacid content of the seed was analyzed by using ninhydrin method (Moore and Stein, 1948). Protein content of the seed was measured as per the method developed by Lowry et al., (1951).

Carbohydrate content, total soluble sugars were measured by the methods given by Hodge and Hofreiter (1962) and Somogyi (1952) respectively. Superoxide dismutase activity was estimated by the method of Beauchamp and Fridovich (1971). Catalase activity was measured by the method proposed by Luck (1974).

\section{Results and Discussion}

\section{Yield Attributes}

The data in relation to yield and yield attributes of blackgram at harvest as influenced by different organics was recorded in blackgram and presented in table 1. A significant difference with respect to number of pods per cluster was observed among different organic treatments. Inorganic nutrient management practices have put up higher number of pods per cluster. Among organic treatments, significantly higher number of pods cluster ${ }^{-1}$ were recorded in the treatment of seed treatment with beejamrutha + Soil application of ghanajeevamruta as basal + Foliar sprays of jeevamrutha @ 3\% + Foliar sprays of panchagavya @ 3\% ( $\left.\mathrm{T}_{10}\right)$ (4.13) followed by soil application of ghanajeevamruta as basal + Foliar sprays of jeevamrutha@3\% ( $\left.\mathrm{T}_{8}\right)$ (3.93) and foliar sprays of jeevamrutha @ $3 \% \quad\left(\mathrm{~T}_{5}\right) \quad$ (3.9). Significantly lower number of pods per cluster were recorded in the treatment receiving seed treatment with beejamrutha (3.3) which was on par with the soil application of ghanajeevamruta as basal (3.4).

Significant effect of different organic treatments on number of pods per plant at harvest was observed with respect to number of pods plant (table 1). Similar significant differences were recorded in greengram by Somasundaram et al., (2003). Among different treatments, RDF has recorded significantly higher number of pods per plant (48.4) followed by the treatment receiving seed treatment with water along with the RDF (46.2) and integrated organic treatment (46.04). Lowest Number of pods plant ${ }^{-1}$ (31.6) were recorded in treatment of seed treated with beejamrutha $\left(\mathrm{T}_{3}\right)$. Shariff et al., (2017) also reported that combined application of organics recorded significantly higher number of pods per plant in greengram. 
A significant difference in the number of seeds per pod was recorded in blackgram among different treatments (table 1). Among different treatments, significantly higher number of seeds pod-1 were recorded in the treatments $\mathrm{RDF}(6.9)$ followed by combined organic treatment $\left(\mathrm{T}_{10}\right)$ (6.9) and RDF along with seed treated with water (6.8) While lowest number of seeds per pod were recorded in the treatment seed treatment with beejamrutha (5.3). Spraying jeevamrutha @ $3 \%$ at every 10 days recorded higher number of seeds per plant (6.5) due to higher concentration of micronutrients compared to panchagavya spray. But panchagavya foliar spray @3\% has been reported to produce higher number of seeds pod $^{-1}$ compared to control and other treatments in cowpea (Patel et al., 2013), where jeevamrutha was not used.

Significantly highest shelling percentage was recorded in the treatment RDF (55.16), RDF along with the seed treatment with water (54.16) and combined application of organics $\left(\mathrm{T}_{10}\right)$ (table 1).

The highest shelling percentage of the treatments is attributed to the higher number of seeds per pod and hence higher seed weight compared to pod weight in the above treatments. Lower shelling percentage is recorded in treatment receiving seed treatment with beejamrutha (46.45) which is attributed to the lesser number of seeds per pod compared to other treatments.

Significant differences in the seed yield per hectare among different treatments were recorded in blackgram (table 1). Inorganic fertilizer application i.e. RDF and RDF with seed treatment with water recorded significantly higher seed yields of $1008.19 \mathrm{~kg}$ $\mathrm{ha}^{-1}$ and $962.39 \mathrm{~kg} \mathrm{ha}^{-1}$ respectively compared to individual application of natural organics in blackgram. However combined application of natural organics $\left(\mathrm{T}_{10}\right)$ recorded on par seed yield (921.67 $\left.\mathrm{kg} \mathrm{ha} \mathrm{ha}^{-1}\right)$ with inorganic treatments i.e., $\mathrm{T}_{1}$ and $\mathrm{T}_{2}$. Similar results were also reported in greengram by Gopal et al., (2017) and in chickpea by Jitendra kumar et al., (2017).

They opined that such promotory effect of combined organic application was due to the presence of high beneficial microbial count and plant growth promoting substances (PGPR) and micronutrients, thus stimulating growth, yield and quality of crops. Among other treatments, individual spraying of jeevamrutha@3\% for every 10 days $\left(\mathrm{T}_{5}\right)$ and in combination with basal application of ghanajeevamruta $\left(\mathrm{T}_{8}\right)$ recorded significantly high seed yields of $884.53 \mathrm{~kg}$ ha-1 and 880.0 $\mathrm{kg}$ ha-1 respectively, compared to spraying of panchagavya $\left(\mathrm{T}_{6}, \mathrm{~T}_{9}\right)$ and basal application of ghanajeevamruta $\left(\mathrm{T}_{4}\right)$ and seed treatment with beejamrutha $\left(T_{3}\right)$. As jeevamrutha reported to contain high $\mathrm{Zn}, \mathrm{Fe}, \mathrm{Cu}$ and $\mathrm{Mn}$ compared to other natural organics such promotory effect on growth as well as yield was recorded. Among all the treatments beejamrutha seed treatment $\left(\mathrm{T}_{3}\right)$ recorded lowest seed yield $\left(665.56 \mathrm{~kg} \mathrm{ha}^{-1}\right)$ despite it has showed superior seedling vigour index in lab study. The promotory effects of seed treatment was not reflected on later phase of crop growth specially post reproductive growth, thus recorded lowest seed yield.

\section{Seed biochemical attributes}

Total free aminoacids in the seed of blackgram was recorded at harvest. Significantly higher amino acid content $\left(2730.56 \mu \mathrm{g} \mathrm{ml}^{-1}\right.$ and $2445.55 \mu \mathrm{g} \mathrm{ml}^{-1}$ ) of the seed was recorded in the treatments receiving $\mathrm{RDF}$ and RDF along with the seed treatment with water (table 2). Higher aminoacid in the treatments is attributed to the higher nitrogen availability with the mineral nutrients supplied through chemical fertilizers compared to the organics. 
Table.1 Effect of natural liquid organics on yield and yield attributes of blackgram

\begin{tabular}{|c|c|c|c|c|c|}
\hline Treatments & $\begin{array}{l}\text { Number of } \\
\text { pods per } \\
\text { cluster }\end{array}$ & $\begin{array}{l}\text { Number } \\
\text { of pods } \\
\text { per plant }\end{array}$ & $\begin{array}{l}\text { Number of } \\
\text { seeds per } \\
\text { pod }\end{array}$ & $\begin{array}{l}\text { Shelling } \\
\text { percentage } \\
(\%)\end{array}$ & $\begin{array}{c}\text { Seed } \\
\text { yield } \\
(\text { kg ha-1) }\end{array}$ \\
\hline T1 : ANGRAU- ICM package & 4.1 & 48.4 & 6.9 & 55.16 & 1008.19 \\
\hline T2 : T1 (except the seed treatment with water) & 4.13 & 46.2 & 6.8 & 54.16 & 962.39 \\
\hline T3 : Seed treated with Beejamrutha & 3.3 & 31.6 & 5.3 & 46.45 & 665.56 \\
\hline T4 : Soil application of Ghanajeevamruta as basal & 3.4 & 32 & 5.5 & 48.46 & 747.22 \\
\hline T5 : Foliar sprays of Jeevamrutha @3\% (Every 10 days) & 3.9 & 44 & 6.5 & 51.85 & 884.53 \\
\hline T6 : Foliar sprays of Panchagavya @3\% (Every 10 days) & 3.7 & 38 & 5.8 & 48.97 & 762.5 \\
\hline $\begin{array}{l}\text { T7 : Seed treated with Beejamrutha (T3) +Soil application of } \\
\text { Ghanajeevamruta as basal (T4) }\end{array}$ & 3.73 & 36.2 & 5.53 & 50.3 & 822.5 \\
\hline $\begin{array}{l}\text { T8 : Soil application of Ghanajeevamruta as basal (T4) + } \\
\text { Foliar sprays of Jeevamrutha @ 3\% (Every } 10 \text { days) (T5) }\end{array}$ & 3.93 & 43.27 & 6.2 & 52.05 & 880.33 \\
\hline $\begin{array}{l}\text { T9 : Soil application of Ghanajeevamruta as basal (T4) + } \\
\text { Foliar sprays of Panchagavya @3\% (Every } 10 \text { days) (T6) }\end{array}$ & 3.4 & 33.8 & 5.5 & 50.44 & 709.03 \\
\hline $\begin{array}{l}\text { T10 : Seed treated with Beejamrutha (T3) + Soil application } \\
\text { of Ghanajeevamruta as basal (T4) + Foliar sprays of } \\
\text { Jeevamrutha @ 3\% (Every } 10 \text { days) (T5) + Foliar sprays of } \\
\text { Panchagavya @ 3\% (Every } 10 \text { days) (T6) }\end{array}$ & 4.13 & 46.04 & 6.9 & 54.56 & 921.67 \\
\hline Mean & 3.77 & 39.95 & 6.09 & 51.24 & 836.39 \\
\hline SEm \pm & 0.07 & 0.71 & 0.09 & 0.47 & 36.17 \\
\hline $\mathrm{CD}(\mathrm{P}=\mathbf{0 . 0 5})$ & 0.2 & 2.12 & 0.27 & 1.41 & 108.3 \\
\hline
\end{tabular}


Table.2 Effect of natural liquid organics on post harvest biochemical attributes of blackgram

\begin{tabular}{|c|c|c|c|c|}
\hline Treatments & $\begin{array}{l}\text { Carbohydrates } \\
\quad(\text { g g-1) }\end{array}$ & $\begin{array}{l}\text { Proteins } \\
\quad(\%)\end{array}$ & $\begin{array}{l}\text { Aminoacids } \\
(\mu \mathrm{g} \mathrm{ml}-1)\end{array}$ & $\begin{array}{c}\text { Total soluble } \\
\text { Sugars (mg g-1) }\end{array}$ \\
\hline T1 : ANGRAU- ICM package & 0.71 & 25.89 & 2730.56 & 69.8 \\
\hline T2 : T1 (except the seed treatment with water) & 0.69 & 25.4 & 2445.55 & 68.4 \\
\hline T3 : Seed treated with Beejamrutha & 0.59 & 22.19 & 1559.85 & 52.15 \\
\hline T4 : Soil application of Ghanajeevamruta as basal & 0.61 & 22.43 & 1554.46 & 54.58 \\
\hline T5 : Foliar sprays of Jeevamrutha @3\% (Every 10 days) & 0.67 & 24.19 & 1933.33 & 66.7 \\
\hline T6 : Foliar sprays of Panchagavya @3\% (Every 10 days) & 0.6 & 23.83 & 1536.05 & 64.3 \\
\hline $\begin{array}{l}\text { T7 : Seed treated with Beejamrutha (T3) +Soil application } \\
\text { of Ghanajeevamruta as basal (T4) }\end{array}$ & 0.62 & 23.61 & 1544.25 & 59.98 \\
\hline $\begin{array}{l}\text { T8 : Soil application of Ghanajeevamruta as basal (T4) + } \\
\text { Foliar sprays of Jeevamrutha @ } 3 \% \text { (Every } 10 \text { days) (T5) }\end{array}$ & 0.65 & 24.08 & 1862.96 & 58.48 \\
\hline $\begin{array}{l}\text { T9 : Soil application of Ghanajeevamruta as basal (T4) + } \\
\text { Foliar sprays of Panchagavya @ } 3 \% \text { (Every } 10 \text { days) (T6) }\end{array}$ & 0.58 & 22.8 & 1696.3 & 57.68 \\
\hline $\begin{array}{l}\text { T10 : Seed treated with Beejamrutha (T3) + Soil } \\
\text { application of Ghanajeevamruta as basal (T4) + Foliar } \\
\text { sprays of Jeevamrutha @ 3\% (Every } 10 \text { days) (T5) + } \\
\text { Foliar sprays of Panchagavya @3\% (Every } 10 \text { days) (T6) }\end{array}$ & 0.68 & 25.14 & 2229.63 & 66.95 \\
\hline Mean & 0.64 & 23.96 & 1779.3 & 61.9 \\
\hline SEm \pm & 0.055 & 1.33 & 55.251 & 1.18 \\
\hline $\mathrm{CD}(\mathrm{P}=\mathbf{0 . 0 5})$ & N.S. & N.S. & 165.432 & N.S. \\
\hline
\end{tabular}


Table.3 Effect of natural liquid organics on activity of catalase and superoxide dismutase in seed of blackgram

\begin{tabular}{|c|c|c|}
\hline Treatments & $\begin{array}{c}\text { Catalase } \\
\text { (O.D min-1 g-1) }\end{array}$ & $\begin{array}{l}\text { Superoxide dismutase } \\
(\text { O.D min-1 g-1) }\end{array}$ \\
\hline T1 : ANGRAU- ICM package & 26.79 & 1.73 \\
\hline T2 : T1 (except the seed treatment with water) & 24.17 & 1.67 \\
\hline T3 : Seed treated with Beejamrutha & 10.81 & 0.35 \\
\hline T4 : Soil application of Ghanajeevamruta as basal & 11.14 & 0.39 \\
\hline T5 : Foliar sprays of Jeevamrutha @3\% (Every 10 days) & 18.1 & 1.38 \\
\hline T6 : Foliar sprays of Panchagavya @3\% (Every 10 days) & 15.35 & 0.91 \\
\hline $\begin{array}{l}\text { T7 : Seed treated with Beejamrutha (T3) +Soil application of } \\
\text { Ghanajeevamruta as basal (T4) }\end{array}$ & 16.32 & 0.98 \\
\hline $\begin{array}{l}\text { T8 : Soil application of Ghanajeevamruta as basal (T4) + Foliar } \\
\text { sprays of Jeevamrutha @ 3\% (Every } 10 \text { days) (T5) }\end{array}$ & 18.54 & 1.36 \\
\hline $\begin{array}{l}\text { T9 : Soil application of Ghanajeevamruta as basal (T4) + Foliar } \\
\text { sprays of Panchagavya @3\% (Every } 10 \text { days) (T6) }\end{array}$ & 12.6 & 0.65 \\
\hline $\begin{array}{l}\text { T10 : Seed treated with Beejamrutha (T3) + Soil application of } \\
\text { Ghanajeevamruta as basal (T4) + Foliar sprays of Jeevamrutha @ } \\
3 \% \text { (Every } 10 \text { days) (T5) + Foliar sprays of Panchagavya @ 3\% } \\
\text { (Every } 10 \text { days) (T6) }\end{array}$ & 20.81 & 1.54 \\
\hline Mean & 17.46 & 1.1 \\
\hline SE m \pm & 1.19 & 0.012 \\
\hline $\mathrm{CD}(\mathrm{P}=0.05)$ & 3.14 & 0.095 \\
\hline
\end{tabular}


Lower aminoacid was recorded in seed treatment with beejamrutha $\left(1559.85 \mu \mathrm{g} \mathrm{ml}^{-1}\right)$ due to the less available nitrogen to the crop and basal application of ghanajeevamruta $\left(1554.46 \mu \mathrm{g} \mathrm{ml}^{-1}\right)$ to the soil as it takes time for the mineralisation of nutrients into available form when supplied through organics. Similar results were reported by Rao et al., (2010) in maize kernels.

Among different treatments, higher protein content of the seed was recorded in the treatments receiving RDF $(25.89 \%)$ and $\mathrm{RDF}$ along with the seed treatment with water (25.4\%). Higher protein content of the seed is attributed to the increased aminoacid content of the seed since aminoacids are the basic building blocks of proteins. Lower protein content of seed was recorded in seed treatment with beejamrutha (22.19\%) (table 2). Rao et al., (2010) reported significantly higher protein content with RDF compared to other treatments in maize kernels. But application of panchagavya recorded higher seed protein content compared to RDF and other treatments in tomato (Saraswathi et al., 2006), in groundnut (Kumawat et al., 2009)

Carbohydrate content in the blackgram seed among different treatments was recorded at harvest. Higher carbohydrate content of seed was recorded in $\mathrm{RDF}\left(0.71 \mathrm{~g} \mathrm{~g}^{-1}\right)$. Among organic treatments higher carbohydrate content was recorded in the treatment receiving Seed treatment with beejamrutha + Soil application of ghanajeevamruta as basal + Foliar sprays of jeevamrutha@3\% + Foliar sprays of panchagavya @ 3\% $\left(\mathrm{T}_{10}\right)\left(0.68 \mathrm{~g} \mathrm{~g}^{-1}\right)$. Higher carbohydrate content of the seed is attributed to the increased assimilation. Lower carbohydrate content of seed was recorded in treatments receiving seed treatment with beejamrutha. However, No significant difference among the treatments regarding carbohydrate content of seed was observed during the course of study. Application of panchagavya recorded higher seed carbohydrate content compared to control in greengram (Jayachitra and Vanitha, 2016), in Spinacea oleracea (Sailaja et al., 2014).

Data regarding the total soluble sugar of seed as influenced by different organics was recorded after harvest in blackgram and was reported in the table 2 . Significantly higher soluble sugar content was recorded in the treatments RDF (69.80 $\mathrm{mg} \mathrm{g}^{-1}$ ) and RDF along with the seed treatment with water $(68.4 \mathrm{mg} \mathrm{g}$ $\left.{ }^{1}\right)$. Lower soluble sugar content of seed was recorded in seed treatment with beejamrutha (52.15 mg $\left.\mathrm{g}^{-1}\right)$. The application of panchagavya recorded higher soluble sugar content of seed compared to NPK and control in broccoli (Sanwal et al., 2007), in rice (Vijayan and Krishnaswamy, 2014).

\section{Antioxidant enzymes}

Significant difference among the treatments regarding catalase activity of seed was observed. Significantly higher catalase activity in seed was recorded in the treatments RDF $\left(\mathrm{T}_{1}\right)$ and RDF along with the seed treatment with water $\left(\mathrm{T}_{2}\right)$. Lower catalase activity of seed was recorded in treatments seed treated with beejamrutha and soil application of ghanajeevamruta (table 3).

Superoxide dismutase activity of harvested seed measured in blackgram as influenced by different organics was presented in the table 3 . Significant difference among the treatments regarding superoxide dismutase activity of seed was observed. Significantly higher SOD activity in seed was recorded in the treatments RDF (1.73 O.D min $^{-1} \mathrm{~g}^{-1}$ ) and RDF along with the seed treatment with water (1.67 O.D min $^{-1}$ $\left.\mathrm{g}^{-1}\right)$. Lower SOD activity of seed was recorded in treatment receiving seed treatment with beejamrutha (0.35 O.D $\min ^{-1} \mathrm{~g}^{-1}$ ). Among the inorganic and natural liquid organics used in the field study, the inorganic fertilizers (RDF 
$\left(\mathrm{T}_{1}\right)$ and RDF with seed priming with water $\left(\mathrm{T}_{2}\right)$ ) showed significantly higher yield attributes and yield compared to natural organic applications. Among natural organics used, combined use of natural organics $\left(\mathrm{T}_{10}\right)$ recorded on par seed yields compared to inorganic treatments $\left(T_{1}, T_{2}\right)$ and observed significantly higher values than their individual applications. It denotes that adopting integrated method of natural organic application i.e., seed treatment, soil application and foliar sprays can give optimum seed yields in blackgram. Hence, the combined use of natural organics can be recommended in blackgram. Among the natural liquid organics used as foliar sprays jeevamrutha spray @ 3\% at every 10 days was found superior compared to panchagavya foliar spray, ghanajeevamruta soil application and beejamrutha seed treatment. However, post harvest seed quality attributes i.e. total carbohydrates, total sugars, crude protein and total aminoacids were not affected much by the treatments.

\section{References}

Beauchamp, C., and Fridovich, I. 1971. Superoxide dismutase: improved assays and an assay applicable to acrylamide gels. Annals Biochemistry. 44(1):276-87.

Gopal, L. C., Sharma, S. K., Pal Singh, K., Choudhary, S., and B.R. Bazaya, B.R 2017. Effect of Panchagavya on Growth and Yield of Organic Blackgram [Vigna mungo (L.) Hepper]. International journal of current microbiology and applied sciences. 6(10): 1627-1632.

Hodge, J. E., and Hofreiter, B. T. 1962. In: Methods in Carbohydrate Chemistry (eds Whistler, R L and Miller, J.N) Academic Press New York.

Jayachitra, J., and Vanitha, R. 2016. Effect of panchagavya with neem to promote green gram and analyse the Biochemical changes. International Journal of Research in Pharmacology and Pharmacotherapeutics. 5(2):115122.

Jitendra Kumar, Y., Sharma, M., Yadav, R.N., Yadav, S.K., and Saroj, Y. 2017. Effect of different organic manures on growth and yield of chickpea (Cicer $\begin{array}{lll}\text { arietinum } & \text { L.). Journal of }\end{array}$ Pharmacognosy and Phytochemistry. 1857-1860.

Kumawat, R. N., Mahajan, S. S., and Mertia, R.S. 2009. Growth and development of groundnut (Arachis hypogaea L.) under foliar application of panchgavya and leaf extracts of endemic plant. Indian Journal of Agronomy. 54(3): 324-331.

Lakshmipathi, R. N., 2012. Identification of beneficial microflora in liquid organic manures and biocontrol formulations and their influence on growth and yield of finger millet (Eleusine coracana L.) and field bean (Dolichos lablab L.). Ph.D. Thesis. University of Agricultural Sciences, Banglore, India.

Lowry, O. H., Rosebrough, N. J., Farr, A. L., and Randall, R.J. 1951. Protein measurement with folin- phenol reagent. Journal of Biology and Chemistry. 193: 265-275.

Luck, H., 1974. Catalase in Methods of enzymatic analysis. edited by Bergmeyer, J and Grabi, M. Academic press. Newyork. 895-897.

Moore, S., and Stein, W. H. 1948. Photometric Ninhydrin Method for use in the Chromatography of Amino Acids. Journal of Biology and Chemistry. 176:367-388.

Patel, M. M., Patel, D. M., and Patel, K. M. 2013. Effect of panchagavya on growth and yield of cowpea (Vigna unguiculata (L.). AGRE. 2(3): 313317. 
Rao, K., Srinivasula Reddy, D., and Jogi Naidu, G. 2010. Quality parameters of maize as affected by organic farming. Green farming, 1(4):373- 376.

Sailaja, V., Naga Ragini, N., Dileep Kumar, K., Rajasekhar Reddy, B., and Satyanarayana, S.V. 2014. Effect of foliar application of panchagavya on growth and development of leafy vegetable Spinacia oleracea. International Journal of Agricultural and Food Science. 4(4): 119-122.

Sanwal S. K., Laxminarayana K., Yadav R. K., Rai N., Yadav D. S., and Mousumi, B. 2007. Effect of organic manures on soil fertility, growth, physiology, yield and quality of turmeric. Indian Journal of Horticulture. 64 (4): 444-449.

Saraswathi, T., Vadivel, E., Rajamani, K., Hemalatha, P., and Venkatesan, S. 2006. Comparative performance of panchakavya and growth regulators in increasing growth and yield of tomato. South Indian Horticulture. 54(6): 181185.

Shariff, F. A., Ashok, S. S., Babalad, H. B., Nagaraj, L. B., and S. Giresh, P. 2017. Effect of organics on seed yield and quality of green gram (Vigna radiata
L.) Legume Research. 40 (2): 388-392. Shyamrao, K., Upperi, S. N and Jadhav, R. L., 2016. Greengram productivity enhancement through foliar spray of nutrients. Legume Research. 39(5):814-816

Singh, R. P., 2009. Status paper on pulses. Government of India Ministry of Agriculture (Department of Agriculture and Cooperation). Directorate of Pulses Development. Vindhyanchal Bhavan, Bhopal.

Somasundaram, E., Sankaran, N., Meena, S., Thiyagarajan, T.M., Chandaragi, K. K., and Panneerselvam, S. 2003. Response of greengram to varied concentrations of panchgavya (Organic nutrition) foliar application. Madras Agriculture Journal. 90(3): 169-172.

Somogyi, M., 1952. Notes on sugar determination. Journal of Biological Chemistry. 195: 19-24.

Vijayan, R., and Krishnaswamy, V. 2014. Impact of organic techniques of seed crop management on seed yield and quality in rice. Journal of Applied and Natural Science. 6 (2): 857 - 868.

www.Indiastat.com

\section{How to cite this article:}

Bhargavi, Y., P. Sudhakar, V. Raja Rajeswari and Giridhara Krishna, T. 2021. A Comparative Assessment of Fertilizers and Natural Organics on Yield and Seed Quality Attributes of Blackgram. Int.J.Curr.Microbiol.App.Sci. 10(05): 306-315.

doi: https://doi.org/10.20546/ijcmas.2021.1005.038 